\title{
Is There Social or Monetary Dumping in the European Union? Manufacturing Competitiveness in Central and Eastern Europe
}

\author{
Andrea Ricci
}

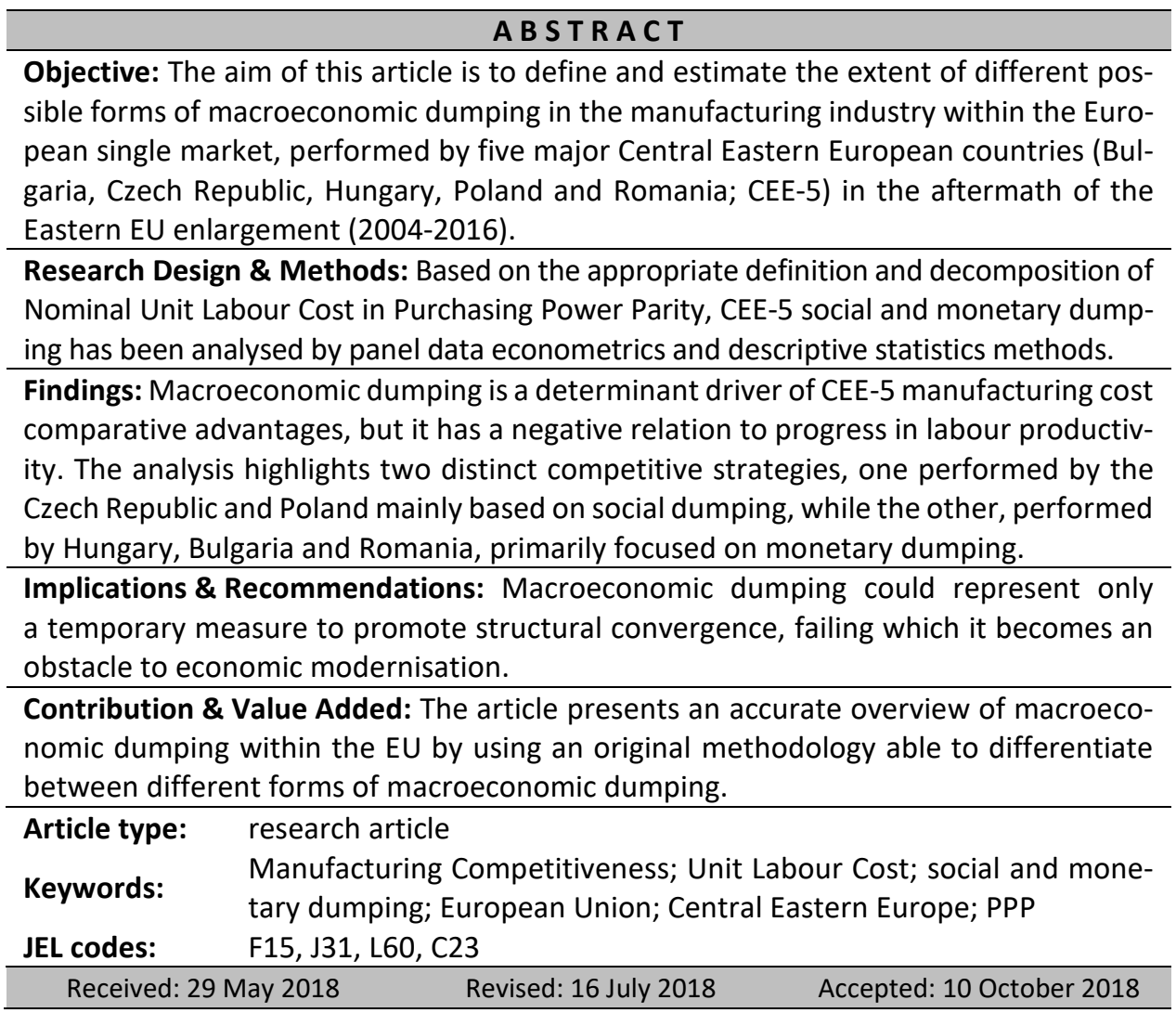

\section{Suggested citation:}

Ricci, A. (2019). Is There Social or Monetary Dumping in the European Union? Manufacturing Competitiveness in Central and Eastern Europe. Entrepreneurial Business and Economics Review, 7(1), 159-180. https://doi.org/10.15678/EBER.2019.070109 


\section{INTRODUCTION}

Since the two rounds of Eastern enlargement of the European Union (EU) in 2004 and 2007, a process of change in the spatial distribution of European manufacturing production has been currently taking place because of diversified trends across countries. In the Euro Area (EA), recurring cases of delocalisation of industrial firms in Central and Eastern Europe (CEE), and the related loss of thousands of jobs have been a cause of great popular concern contributing to the rise of anti-European sentiment in large sections of population. This sentiment was reflected in several recent political elections with the rise of populist parties, for example in France, Germany and Italy. In the political and popular debate, the matter of controversy relates to suspected practices of unfair competition arising from dumping policies implemented by the CEE countries within the European single market. As Rodrik (2018) points out, indeed, social dumping is one of the most relevant economic roots of 'populism' in the actual globalised world.

Compared to the intensive political and popular discussion, in economic literature relatively little attention is devoted to assessing the real dimension of dumping practices in determining relative cost advantages within the European single market. The article aims at filling the gap by detecting the size of macroeconomic dumping in the EU manufacturing industry, and the different forms in which it is carried out in the five major CEE countries (CEE-5: Bulgaria, Czech Republic, Hungary, Poland and Romania) not belonging to the EA. The hypotheses under examination, through panel data econometrics and descriptive statistic tools, concern the relevance of macroeconomic dumping in determining the performance of the CEE- 5 manufacturing industry, and the different strategies performed by the CEE- 5 to gain cost-price competitiveness.

The article is organised as follows. The first part discusses the controversial definition of macroeconomic dumping with various forms that it can assume, and presents a critical review of the significance of Nominal Unit Labour Cost (NULC) in international comparisons of relative industrial competitiveness. The second part is devoted to the methodology and data used in the empirical research, and the discussion of its results. An original decomposition of the Unit Labour Cost is presented to allow for different forms of dumping, representing the basis for subsequent econometric and statistical analysis. Finally, the article ends with some concluding remarks, whose general implications are that macroeconomic dumping could represent only a temporary measure to promote structural convergence, failing which it becomes an obstacle to economic modernisation.

\section{LITERATURE REVIEW AND THEORY DEVELOPMENT}

\section{Recent Trends in the EU Manufacturing Production}

In the period of 2004-2016, the share in volume of the CEE-5 in total EU manufacturing production significantly increased from $5.6 \%$ in 2004 to $8.9 \%$ in 2016, in the face of a declining share of the production localised in the Euro Area countries (EA $-0.8 \%,)^{1}$. Similar trends are occurring in manufacturing employment too, with an increase of 137000 employed persons

\footnotetext{
${ }^{1}$ Source Eurostat database: National accounts aggregates by industry [nama_10_a64], NACE Rev. 2 C Manufacturing, chain linked volumes (2005), million euro.
} 
in the CEE-5 and a loss of 2750.000 employed persons in the EA. The corresponding shares in total EU manufacturing employment has increased from $21.6 \%$ to $24.5 \%$ in the CEE-5, and fallen from $66 \%$ to $64 \%$ in the EA, respectively ${ }^{2}$. These divergent trends are clearly reflected in the cumulated growth in the volume of production and intra-EU exports of manufactured goods, which have been considerably higher in each of the CEE-5 countries than in the EA (Figure 1). In this period the main driver of CEE export competitiveness has been the expansion of market share within the European single market (Gilbert \& Muchová, 2018).

The growth in the manufacturing sector in CEE is, among other things, a consequence of the delocalisation of production by foreign European and non European firms (Labrianidis, 2016; Totev \& Sariisk 2010). During the period of 2005-2013, the per capita inward stock of foreign direct investment in the CEE-5 continued to grow (Jantoń-Drozdowska \& Majewska, 2016), albeit at a slower rate after the crisis of 2008 (Voicu, Sen, \& Martinez-Zarzoso, 2018). As a result of this trend, the value added produced by foreign controlled enterprises is significantly higher in the CEE-5 than in the rest of the EU (Myant, 2018). In total business economy, except financial and insurance activities, in 2014 the value added at factor cost produced by foreign firms was $33.1 \%$ in Bulgaria, $42.3 \%$ in Czech Republic, $52.7 \%$ in Hungary, $35.4 \%$ in Poland and $43.9 \%$ in Romania, in the face of a EU average of $24.3 \%^{3}$. Because of this high level of foreign ownership and control by multi-national companies, the CEE economies has been recognised as forms of 'dependent market economies', in which the comparative advantage derives primarily from the relatively low labour cost of their skilled workers (Nölke \& Vliegenthart, 2009; Myant \& Drahokoupil, 2012; Drahokoupil \& Myant, 2017).

The relative performance of CEE-5 manufacturing production and exports indicates the presence of a sectoral cost-price competitive advantage. Although technological and institutional competitiveness are other important non-price components (Benkovskis \& Wörz, 2012; Bierut \& Kuziemska-Pawlak, 2017), cost advantages are of paramount importance in the actual global competitive environment. The unit labour cost, in particular, represents a major determinant of foreign domestic investment (FDI) flows in CEE's countries (Bellak, Leibrecht, \& Riedl, 2008). Since capital mobility in the form of FDI by multinational companies is a crucial mechanism of dumping within the EU (Adnett, 1995; Aspinwall, 1996; Meardi, Strohmer, \& Traxler, 2013; Krzywdzinski, 2014), the question of dumping practices within the European single market has become increasingly relevant in the political and institutional debate (Kiss, 2017). However, if at the microeconomic level the concept of dumping is well established, the same cannot be said at the macroeconomic level. The next section is devoted to clarification of this point.

The concept of dumping originates in the microeconomic theory to indicate the price discrimination behaviour of monopolistic firms within segmented markets, in which the prices of two similar goods are in different ratios to marginal costs (Varian, 1989). This notion has been applied in the microeconomic international trade theory to describe the ability of oligopolistic firms to discriminate between foreign and domestic markets because of different demand elasticities, and used to explain intra-industry trade in identical products (Brander \& Krugman, 1983; Krugman, 1995). The macroeconomic definition of dumping is, however,

\footnotetext{
${ }^{2}$ Source Eurostat database: Employment by A*10 industry breakdowns [nama_10_a10_e], NACE Rev. 2 C Manufacturing, Thousand persons, Total employment domestic concept.

${ }^{3}$ Source Eurostat database: Value Added in Foreign Controlled Enterprises [egi_va1].
} 
more problematic because it refers to the structural characteristics of a national economy, and it is strongly influenced by state policy issues (Maslauskaitè, 2013; Bernaciak, 2015).

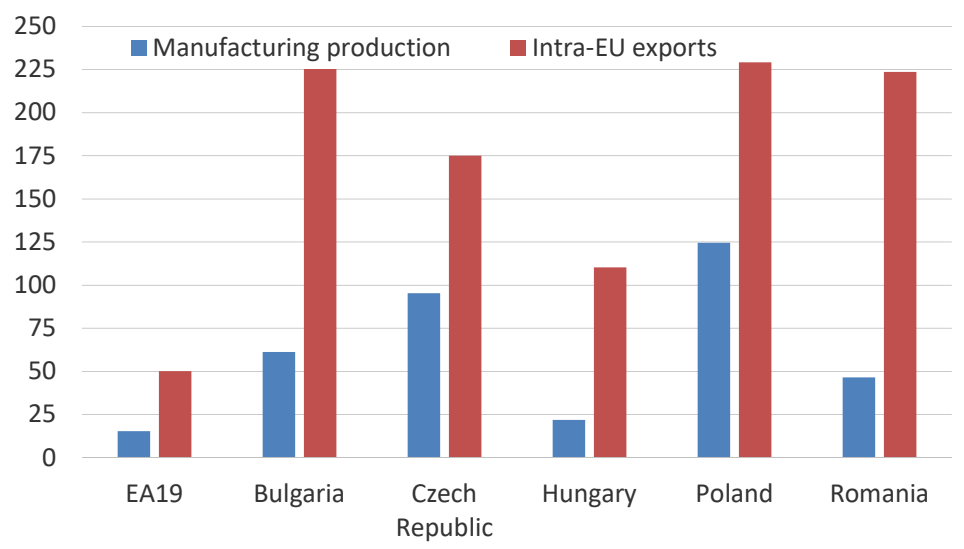

Figure 1. Manufacturing production (volume) and intra EU exports: 2004-2016, total \% change Source: own calculations from Eurostat database.

In literature, we can find different forms of macroeconomic dumping (Larsson, 1996). The first form relates to lower regulating labour legal standards with respect to other countries competing in the same integrated market. In this situation, commonly referred to as social dumping (Albert \& Standing, 2000), the unfair advantage consists in a downward competition on the worker's conditions aimed at reducing labour costs. Social dumping includes three different practices of unfair competition. The first two (Sinn, 2008) relate to welfare dumping deriving from lower monetary and in kind social benefits to workers, and wage dumping from lower net wages. The third practice is fiscal dumping deriving from lower taxes paid on labour (Andersen, 2003; Merlevede, Rayp, Van Parys, \& Verbeke, 2011).

In the debate concerning social dumping in Europe, two different positions have been expressed. According to some authors (Vaughan-Whitehead, 2003; Scharpf, 2010; Höpner \& Schäfer, 2012; Crespy \& Menz, 2015; Meardi, 2017; Hyman, 2018), the market-oriented European integration process has led to a race to the bottom in wages and welfare conditions, so undermining the salient features of the social compromise reached in Western Europe after the Second World War. In this contest of market deregulation, the Eastern EU's enlargement to countries with a poor tradition in 'social modelling' of industrial relations would amplify the problem (Cremers, 2016). This view is supported by the empirical evidence of a slow or null wage convergence among neighbouring regions across international borders within the EU (Naz, Ahmad, \& Naveed, 2017). Other authors (Caporaso \& Tarrow, 2009; Rubery, 2011; Vaughan-Whitehead, 2015; Athanasenas, Chapsa, \& Michailidis, 2015), in contrast, pointed out the gradual convergence process in the definition of common social standards, resulting from the transition to an economic and monetary union equipped with regulatory powers valid for all Member States.

The second form of macroeconomic dumping refers to monetary dumping deriving from systematic real undervaluation of the domestic currency with respect to its long run equilibrium position, defined as the purchasing power parity (PPP) exchange rate. Monetary dumping is a consequence of direct and indirect government interventions on exchange markets 
(currency manipulation), or distortions in the international monetary and financial system (Auboin \& Ruta, 2013). With regard to the monetary regimes of the CEE-5, according to the IMF classification (International Monetary Fund, 2018), three of them (Hungary, Poland and Romania) are adopting a floating exchange rate, Bulgaria has had a currency board since 1997 and the Czech Republic maintains an exchange rate anchor to EUR. Notwithstanding these differences, the actual exchange rate of all of them can be statistically well approximated by a soft peg to a currency basket dominated by EUR (Slavov, 2017). This occurs to an extent which cannot be explained by inflation targeting or economic and financial integration, thereby leaving the question of the real goals of their exchange rate policy open.

Both forms of dumping, social and monetary, have the same effect on domestic industrial competitiveness, reducing the labour cost per unit of product by policy manipulations, and not through improvements in labour productivity and technological efficiency. There are, however, important differences between the two forms of dumping. Social dumping directly deteriorates the living and working conditions of a large section of domestic labour force, while monetary dumping acts primarily on the competitor countries, having a down pressure on the foreign living and working conditions. Furthermore, the blame of social dumping lies entirely with domestic economic policies, while, for countries with convertible currency, monetary dumping is a consequence of bilateral exchange rate policies and objective conditions of international financial markets.

\section{The Unit Labour Cost and Industrial Competitiveness}

The Unit Labour Cost (ULC) is defined as the ratio between labour compensation per unit of labour and labour productivity. Normally, the measure of total labour is differentiated between numerator and denominator because labour cost is divided by a measure of labour employed, while output by a measure of total labour comprising self-employment to take into account differences in employment structures (Hinze, 1998). In this form, the ULC shows that the cost competitiveness of an industry can be improved by a decrease in unit wage or by an increase in total labour productivity (Van Ark, Stuivenwold, \& Ypma, 2005).

In international comparisons, the ULC is often preferred over other indicators of competitiveness ${ }^{4}$ because the labour cost is the greater non tradable component of the cost of production, slightly sensitive to short run erratic fluctuations in imported input prices (Turner \& Van't dack, 1993; Turner \& Golub, 1997). As evidenced by the European Commission (2009, p. 29), in the presence of integrated labour markets wherein wages reflect the average national productivity level, a sectoral ULC lower than average is a good indicator of comparative advantages in the international trade, notably in the manufacturing industry in which tariff and non tariff barriers are usually lower than other sectors.

At national level, the ULC can be calculated by different methods. The method used by Eurostat considers nominal values for both variables of the ratio (the so-called Real Unit Labour Cost or RULC), indicating the wage share in total value added. In recent literature, some authors (Borbély \& Neumann, 2015; Popovici, 2015; Botrić \& Broz, 2016; Artner, 2017) have taken this approach to examine CEE competitiveness. RULC, however, expresses the functional distribution of income between labour and capital, and its relation

\footnotetext{
${ }^{4}$ For a review of international competitiveness indicators see Ca'Zorzi and Schnatz (2007); Siggel (2010); Siudek and Zavojska (2014).
} 
to industrial competitiveness is ambiguous (Felipe \& Kumar, 2011; Kyrkilis, Makris, \& Hazakis, 2016), because of the possible presence of the Kaldor's paradox (Kaldor, 1978), according to which an increasing wage share could be a factor enhancing the long term rate of growth and international trade share of an economy. Furthermore, changes in relative RULC can be caused by changes in prices rather than in production efficiency, as is the case of different wage indexation between industries or countries (ILO, 2013).

The method used by most of the international institutions (European Central Bank, Organisation for Economic Cooperation and Development, European Commission) to avoid these problems relates nominal unit labour compensation to real labour productivity, by expressing labour cost in current nominal terms and output in constant price terms. This indicator, called Nominal Unit Labour Cost in national currency $\left(N U L C_{n c}\right)$, can be represented by the following equation:

where:

$$
N U L C_{n c}=\left(\frac{W_{n c}}{L_{e}} / \frac{Y_{n c}}{L_{t o t}}\right)
$$

$W_{n c}$ - total labour compensation in national currency;

$L_{e}$ - labour of employees;

$Y_{n c}$ - value added at constant price in national currency;

$L_{\text {tot }}$ - total labour.

In this way, $N U L C_{n c}$ shows the inflationary pressure deriving from nominal wages growth, which deteriorates the cost competitiveness of an industry or an economy. A lower $N U L C_{n c}$ is thus an index of comparative cost advantage of a firm or an industry. The issue which arises in international comparisons is how to express $N U L C_{n c}$ of different countries in a common and equivalent unit of account (Felipe, 2007). $N U L C_{n c}$, indeed, can be used to analyse the evolution of the competitiveness of a country during a given period of time, due to the relative dynamics of wages and productivity, but not between different countries because of the different units of accounts in calculating labour cost. A common method to bypass this problem is to convert labour cost in a common currency (i.e. dollar or EUR) by applying current nominal exchange rates. Recently, some authors (Honkapohja \& Korhonen, 2013; Rozmahel, Grochová, \& Litzman, 2016; Dautović, Orszaghova, \& Schudel, 2017) used this indicator to analyse relative industrial competitiveness of CEE economies.

This solution, however, makes it possible to compare the change in relative competitiveness between countries during an interval of time, but not the absolute levels of competitiveness, which represents the key variable determining the comparative advantage of a national industry (Oulton, 1994). In order to internationally compare the absolute level of cost competitiveness, it is necessary to convert labour productivity in a common currency, too. In this matter, the use of current nominal exchange rates clashes with the problem of the systematic misalignment of current exchange rates with respect to their long run equilibrium position, the so called purchasing power puzzle (Rogoff, 1996). By applying this method, real labour productivities would be distorted by different price levels between countries, not cancelled by the short run equilibrium of exchange rates in currency markets. For this reason, it is preferable to use the purchasing power parity (PPP) exchange rates to measure real labour productivity of different countries (Van Ark \& Monnikhof, 2000). 
The indicator which better approximates the level of international competitiveness of an industry is therefore the ratio between nominal unit labour compensation converted in current exchange rates and real productivity measured in PPP exchange rates $\left(N U L C_{P P P}\right)$, expressed by the following formula:

where:

$$
N U L C_{P P P}=\left(\frac{E W_{n c}}{L_{e}} / \frac{E_{P P P} Y_{n c}}{L_{t o t}}\right)
$$

\footnotetext{
$E$ - current exchange rate;

$E_{P P P}$ - PPP exchange rate.
}

Expression (2) has been used by some authors to compare the absolute levels of national industrial competitiveness (see, among others, Hooper and Vranlovich, 1995; Vecernik, 2001; Felipe and Sipin, 2004; Havlik, 2005; He, You and Mo, 2009; Author, 2015) and by Erickson and Kuruvilla (1994) to analyse the size of social dumping within the EU. An appropriate decomposition of NULCPPP will be the basis of the empirical analysis described below.

\section{MATERIAL AND METHODS}

Defining unit labour cost as the ratio between total labour compensation and labour of employees, and labour productivity as the ratio between value added in constant price and total labour, expression (2) can be rewritten as follows:

where:

$$
N U L C_{P P P}=\frac{E l c_{n c}}{E_{P P P} l p_{n c}}
$$

$l c_{n c}$ - unit labour cost in national currency;

$l p_{n c}$ - labour productivity in national currency.

By defining the ratio between current and PPP exchange rate as Exchange Rate Deviation Index (ERDI), expression (3) becomes the following:

where:

$$
N U L C_{P P P}=N U L C_{n c} E R D I
$$

$$
E R D I=\frac{E}{E_{P P P}}
$$

Expression (4) shows that $N U L C_{P P P}$ can be divided into two components, the first $\left(N U L C_{n c}\right)$ representing the domestic factors of competitiveness (national wages and labour productivity), while the second (ERDI) the monetary factor relating to the difference between current and long run equilibrium exchange rate. In the case of actual currency undervaluation with respect to long run equilibrium $(E R D I<1)$, the monetary factor reinforces the international competitiveness of a country by reducing $N U L C_{P P P}$, and vice versa in the case of actual currency overvaluation $(E R D I>1)$.

Since total labour compensation paid by employers to employees is the sum of social contributions for welfare benefits of workers $(s c)$, taxes on labour $(t /)$ and net wages $(n w), N U L C_{n c}$ in turn it can be decomposed into different factors, as follows:

$$
N U L C_{P P P}=\left(N U L C_{n c}^{s c}+N U L C_{n c}^{t l}+N U L C_{n c}^{n w}\right) E R D I
$$

In expression (5), the international competitiveness index has been decomposed into four factors, of which the first three (welfare, fiscal and net wage factors) represent the 
domestic social component of the international competitiveness of a country, while the fourth its monetary component related to the exchange rate policy.

To compare the levels of $N U L C_{P P P}$ between CEE-5 and EA, the PPP exchange rates have been normalised to EUR in its actual composition at 19 countries, so that:

$$
E R D I_{E A}=1
$$

and

$$
N U L C_{P P P E A}=N U L C_{n C E A}=N U L C_{E A}
$$

For each CEE-5, the indicator of relative competitiveness with respect to the $E A$ manufacturing industry is the following:

$$
N U L C_{P P P}-N U L C_{E A}=E R D I N U L C_{n c}-N U L C_{E A}
$$

By adding and subtracting $N U L C_{n c}$ from the second member of the equation, we obtain the following expression:

$$
N U L C_{P P P}-N U L C_{E A}=\left(N U L C_{n c}-N U L C_{E A}\right)+(E R D I-1) N U L C_{n c}
$$

The first factor of the right-side of equation (9), that is the difference between NULCS in national currency, represents the domestic social component of the CEE- 5 relative competitiveness, while the second factor represents the monetary component of the exchange rate misalignment.

We define a situation of dumping if the relative cost advantage expressed by expression (9) is associated with a domestic PPP labour productivity lower than foreign labour productivity, depending entirely on lower labour cost. In this case, decomposing $N U L C_{n c}$ and $N U L C_{E A}$ into their different social components helps to discriminate between different sources of dumping (welfare, fiscal and wage dumping), as in the following expression:

$$
\begin{aligned}
N U L C_{P P P}- & N U L C_{E A}=\left(N U L C_{n c}^{s c}-N U L C_{E A}^{s c}\right)+\left(N U L C_{n c}^{t l}-N U L C_{E A}^{t l}\right)+ \\
& +\left(N U L C_{n c}^{n w}-N U L C_{E A}^{n w}\right)+(E R D I-1) N U L C_{n c}
\end{aligned}
$$

The empirical analysis is carried out in two steps. The first step tests, by a panel regression analysis, the significance of NULCPPP and its decomposition in the CEE-5 manufacturing competitiveness. In the second step, descriptive comparative analysis is used to evaluate the different competitive strategies adopted by the CEE-5.

\section{Data}

Eurostat Database ${ }^{5}$ was the source of the following data:

- Value added in Manufacturing at current prices in million units of national currency and million EUR [nama_10_a64];

- Value added in Manufacturing, chain linked volume (2005) in million units of national currency and million EUR [nama_10_a64];

- Compensation of employees in Manufacturing, current prices in million units of national currency and million EUR [nama_10_a64];

- Wages and salaries in Manufacturing, current prices in million units of national currency and million EUR [nama_10_a64];

- Thousand hours worked in Manufacturing, Total employment domestic concept [nama_10_a10_e];

\footnotetext{
${ }^{5}$ See http://ec.europa.eu/eurostat/data/database
} 
- Thousand hours worked in Manufacturing, Employees domestic concept [nama_10_a10_e];

- Thousand hours worked in Manufacturing, Self-employed domestic concept [nama_10_a10_e];

- EUR/ECU exchange rates - annual data, average [ert_bil_eur_a];

- Purchasing power parities, Total goods 6 [prc_ppp_ind]:

- Intra and Extra-EU trade by Member State and by product group [ext_It_intratrd]. Exports in million of EUR.

The European Commission ${ }^{7}$ was the source of data on taxes on labour.

The data used have an annual frequency and the period considered is between 2004, the year of the first major Eastern EU enlargement, and 2016.

\section{RESULTS AND DISCUSSION}

As discussed previously, there is macroeconomic dumping when a lower $N U L C_{p p p}$ is associated with a lower PPP labour productivity, the higher competitiveness being entirely determined by lower labour cost. As Tables 1 and 2 show, this condition occurs for each of the CEE-5 countries with respect to the EA. In dynamic terms, we can divide the five CEE countries into two distinct groups characterised by different temporal trends. In the first group, including the Czech Republic and Poland, the relative level of NULCPPp remains stable or decreases during the period, while in the second group, including Hungary, Bulgaria and Romania, it increases, whilst continuing to be significantly lower than the EA. These trends are reflected in relative labour productivity position too, with the first group experiencing a significant improvement, and the second group a stagnation.

Table 1. Manufacturing PPP labour productivity level 2004-2016. Euro Area $=100$

\begin{tabular}{|l|c|c|c|c|c|c|c|c|c|c|c|c|c|}
\hline \multicolumn{1}{|c|}{ Area } & $\mathbf{2 0 0 4}$ & $\mathbf{2 0 0 5}$ & $\mathbf{2 0 0 6}$ & $\mathbf{2 0 0 7}$ & $\mathbf{2 0 0 8}$ & $\mathbf{2 0 0 9}$ & $\mathbf{2 0 1 0}$ & $\mathbf{2 0 1 1}$ & $\mathbf{2 0 1 2}$ & $\mathbf{2 0 1 3}$ & $\mathbf{2 0 1 4}$ & $\mathbf{2 0 1 5}$ & $\mathbf{2 0 1 6}$ \\
\hline Euro area & 100 & 100 & 100 & 100 & 100 & 100 & 100 & 100 & 100 & 100 & 100 & 100 & 100 \\
\hline Bulgaria & 15 & 15 & 15 & 15 & 13 & 13 & 16 & 16 & 15 & 16 & 16 & 16 & 16 \\
\hline Czech Republic & 40 & 44 & 52 & 52 & 55 & 49 & 63 & 63 & 57 & 56 & 59 & 58 & 58 \\
\hline Hungary & 37 & 38 & 39 & 39 & 38 & 30 & 42 & 39 & 36 & 37 & 37 & 39 & 37 \\
\hline Poland & 30 & 28 & 30 & 30 & 30 & 29 & 40 & 39 & 38 & 39 & 40 & 41 & 40 \\
\hline Romania & 20 & 20 & 21 & 20 & 22 & 20 & 25 & 23 & 20 & 21 & 22 & 23 & 23 \\
\hline
\end{tabular}

Source: own elaboration based on Eurostat Database.

\section{NULCppp and Social and Monetary Dumping as Indicators of Competitiveness}

The hypotheses under test concern the existence of a systematic causal relation between the economic performance of the CEE-5 manufacturing industry and the level and composition of $N U L C_{p p p}$. The dependent variables are: a) CEE-5 gross industry value added measured in EUR at constant prices 2005 (Y_CEE5); b) CEE-5 intra-EU exports measured in EUR at current prices (EXEU_CEE5); c) share of Y_CEE5 in total EU gross manufacturing value

\footnotetext{
${ }^{6}$ PPP exchange rates were calculated on total goods, with the exclusion of services, because they better approximate price differences in manufacturing industry.

${ }^{7}$ See https://ec.europa.eu/taxation_customs/business/economic-analysis-taxation/data-taxation_en
} 
Table 2. Level of NULCppp in Manufacturing 2004-2016. Euro Area $=100$

\begin{tabular}{|l|c|c|c|c|c|c|c|c|c|c|c|c|c|}
\hline \multicolumn{1}{|c|}{ Area } & $\mathbf{2 0 0 4}$ & $\mathbf{2 0 0 5}$ & $\mathbf{2 0 0 6}$ & $\mathbf{2 0 0 7}$ & $\mathbf{2 0 0 8}$ & $\mathbf{2 0 0 9}$ & $\mathbf{2 0 1 0}$ & $\mathbf{2 0 1 1}$ & $\mathbf{2 0 1 2}$ & $\mathbf{2 0 1 3}$ & $\mathbf{2 0 1 4}$ & $\mathbf{2 0 1 5}$ & $\mathbf{2 0 1 6}$ \\
\hline Euro area & 100 & 100 & 100 & 100 & 100 & 100 & 100 & 100 & 100 & 100 & 100 & 100 & 100 \\
\hline Bulgaria & 39 & 44 & 45 & 47 & 55 & 60 & 55 & 56 & 63 & 63 & 64 & 68 & 73 \\
\hline Czech Republic & 58 & 55 & 52 & 56 & 56 & 65 & 48 & 51 & 56 & 55 & 52 & 50 & 52 \\
\hline Hungary & 51 & 56 & 56 & 56 & 66 & 75 & 54 & 64 & 68 & 66 & 64 & 61 & 68 \\
\hline Poland & 46 & 46 & 48 & 51 & 58 & 61 & 42 & 46 & 47 & 46 & 44 & 45 & 47 \\
\hline Romania & 34 & 41 & 51 & 60 & 78 & 52 & 43 & 47 & 60 & 51 & 53 & 55 & 59 \\
\hline
\end{tabular}

Source: own elaboration based on Eurostat Database.

added (SHY_CEE5); d) ratio between CEE-5 and EA PPP labour productivity $(L P p p p)$. The independent variables are the level of $N U L C_{p p p}$ for the first two regressions, and the two components of macroeconomic dumping, social (SOC_DUMP) and monetary (MON_DUMP) as defined by expression (9), for the last two regressions. The models tested are the following:

$$
\begin{gathered}
Y_{-} C E E 5_{t}=a+b N U L C p p p_{t}+c T_{t}+\varepsilon_{t} \\
E X E U_{-} C E E 5_{t}=a+b N U L C p p p_{t}+c T_{t}+\varepsilon_{t} \\
S H Y_{-} C E E 5_{t}=a+b S O C_{-} D U M P_{t}+c M O N_{-} D U M P_{t}+\varepsilon_{t} \\
L P p p p_{t}=a+b S O C_{-} D U M P_{t}+c M O N_{-} D U M P_{t}+\varepsilon_{t}
\end{gathered}
$$

In the first two models, a constant and time trend variable $(T)$ are inserted to assess for systematic and cyclical macroeconomic components. The panel dataset consists of 65 observations, including 5 cross-sectional units observed over 13 periods for each of the CEE-5 countries. The econometric package used for the estimation is GRETL (see Baiocchi \& Distaso, 2003; Cottrell \& Lucchetti, 2012).

For each of the four models, panel Ordinary least square (OLS) estimations with fixed effects have high positive autocorrelation and group-wise heteroskedasticity in the residuals, as showed in Table 3 by Durbin-Watson statistics smaller than 1 , and modified Wald tests with p-values close to 0 . These problems are common in panel regression analysis with a small time interval and interdependence between variables. In that case, OLS method is no longer efficient.

Table 3. OLS Fixed Effects Regressions. Tests For Autocorrelation and Group-Wise Heteroskedasticity in the Residuals

\begin{tabular}{|r|r|r|}
\hline Model & D-W statistic & Wald test: null hypothesis homoskedasticity \\
\hline Model (11) & 0.38338 & Chi2 $(5)=4792.21$ with p-value $=0$ \\
\hline Model (12) & 0.892684 & Chi2 $(5)=75.7071$, with -value $=9.98178 \mathrm{e}-19$ \\
\hline Model (13) & 0.148566 & Chi2 $(5)=903.298$ with p-value $=5.14389 \mathrm{e}-193$ \\
\hline Model (14) & 0.609577 & Chi2 $(5)=19.9887$ with p-value $=0.00125587$ \\
\hline
\end{tabular}

Source: own study.

In the presence of heteroskedasticity and autocorrelation in the errors, a more efficient method of estimation than OLS is the Weighted least squares, WLS (Romano \& Wolf, 2017; Sterchi \& Wolf, 2017; DiCiccio, Romano, \& Wolf, 2018). WLS with weights based on 
per-unit error variances is, therefore, used to estimate our models. In model (13) estimation, the constant is removed to ensure a significantly better R-squared ${ }^{8}$.

The signs of the coefficients are expected as negative, indicating that a lower NULCPPP increases net product and intra-EU exports of the CEE-5, and a higher negative difference between NULC $C_{P P P}$ and $N U L C_{E A}$, both in the social and monetary components, increases the CEE-5 share in total EU manufacturing production and PPP labour productivity.

Table 4. WLS, Using 65 Observations, Included 5 Cross-Sectional Units. Weights Based on PerUnit Error Variances

\begin{tabular}{|c|c|c|c|c|}
\hline \multicolumn{5}{|c|}{ Model (11). Dependent variable: Y_CEE5. R-squared $=0.404339$} \\
\hline Statistics & coefficient & std. error & t-ratio & $p$-value \\
\hline const & 76840.30 & 9523.350 & 8.069 & $3.01 \mathrm{e}-11^{* * *}$ \\
\hline NULCppp & -156107.00 & 24846.100 & 24846.100 & $3.68 \mathrm{e}-08 * * *$ \\
\hline time & 1306.34 & 261.094 & 5.003 & $4.93 \mathrm{e}-06 * * *$ \\
\hline \multicolumn{5}{|c|}{ Model (12). Dependent variable: EXEU_CEE5. R-squared = 0.337226} \\
\hline Statistics & coefficient & std. error & $t$-ratio & $p$-value \\
\hline const & 109311.00 & 23954.600 & 4.563 & $2.44 \mathrm{e}-05 * * *$ \\
\hline NULCppp & -201888.00 & 62967.500 & -3.206 & $0.0021 * * *$ \\
\hline time & 4644.93 & 841.736 & 5.518 & $7.13 \mathrm{e}-07^{* * *}$ \\
\hline \multicolumn{5}{|c|}{ Model (13). Dependent variable: SHY_CEE5. Centered R-squared $=0.623609$} \\
\hline Statistics & coefficient & std. error & t-ratio & p-value \\
\hline SOC_DUMP & -0.0757130 & 0.00569934 & -13.280 & $6.26 \mathrm{e}-20 * * *$ \\
\hline MON_DUMP & -0.0113392 & 0.00662332 & -1.712 & $0.0918 *$ \\
\hline \multicolumn{5}{|c|}{ Model (14). Dependent variable: LPppp. R-squared $=0.723849$} \\
\hline Statistics & coefficient & std. error & t-ratio & $p$-value \\
\hline const & 0.729053 & 0.0593933 & 12.280 & $3.03 \mathrm{e}-18^{* * *}$ \\
\hline SOC_DUMP & 0.150244 & 0.1391440 & 1.080 & 0.2844 \\
\hline MON_DUMP & 2.34260 & 0.2395360 & 9.780 & $3.50 \mathrm{e}-14^{* * *}$ \\
\hline
\end{tabular}

Source: own study.

As showed in Table 4, in the first three regressions the coefficients have the expected sign with a $99 \%$ confidence interval, with the exception of monetary dumping coefficient in the third regression, for which confidence interval is $90 \%$. On the contrary, in the fourth regression the signs of coefficients are the opposite of what was expected, even if the social dumping coefficient is not statistically significant, meaning that an increase in social and monetary dumping corresponds to an increase in PPP labour productivity gap relative to the EA.

Table 5 shows the correlation values between the dependent variables of the models, from which we can see that NULC $C_{p p p}$ of the CEE-5 has a growing temporal trend, and there is an inverse relation between the two forms of dumping.

The conclusions that can be drawn are the following: a) the absolute level of PPP unit labour cost is a good indicator of the competitiveness in the CEE-5 manufacturing industry, despite its increase during the period; b) the suggested decomposition into social and monetary dumping is pertinent; c) both social and monetary dumping contribute to explaining the gain in relative CEE- 5 competitiveness; $d$ ) there is a trade-off

8 In WLS estimation with the constant, R-squared is 0.569277. 
between the two forms of dumping; e) social, and particularly monetary dumping have a negative effect on the CEE-5 labour productivity.

Table 5. Correlations Between Dependent Variables

\begin{tabular}{|c|c|}
\hline Statistics & Correlation coefficient \\
\hline $\begin{array}{l}\text { corr(NULCppp, } \\
\text { time) }\end{array}$ & $\begin{array}{c}0.33455171 \\
\text { Under the null hypothesis of no correlation: } \mathrm{t}(63)=2.81779, \text { with two-tailed } \mathrm{p} \text {-value } 0.0065\end{array}$ \\
\hline $\begin{array}{l}\text { Corr(SOCDUMP, } \\
\text { MONDUMP) }\end{array}$ & $\begin{array}{c}-0.72417109 \\
\text { Under the null hypothesis of no correlation: } \mathrm{t}(63)=-8.33492, \text { with two-tailed } \mathrm{p} \text {-value } 0.0000\end{array}$ \\
\hline
\end{tabular}

Source: own study.

\section{Different Competitive Strategies in the CEE-5 Countries}

Decomposing NULCPPP into monetary and social dumping, by applying expressions (10) and (11), we obtain the results showed in Figures from 2 to 6 . Both monetary dumping and social dumping are factors determining manufacturing cost competitiveness advantage in each of the CEE-5.

As regards the different components of social dumping, we can observe that: a) welfare dumping deriving from lower social contributions is a common feature of all CEE-5; b) fiscal dumping deriving from lower taxes on labour is of limited scale; and c) wage dumping deriving from lower net wages share in net product is present only in the Czech Republic and Poland. Turning to a dynamic overview, the descriptive analysis confirms and clarifies the meaning of the general trade-off between social and monetary dumping revealed in the previous paragraph. The size of monetary dumping has increased from the outbreak of the economic and financial crisis in 2008-2009, following an initial period of monetary convergence within the EU. There are, however, substantial differences between countries. The first group (Czech Republic and Poland) experimented a significant reduction in monetary dumping, in contrast to the second group (Hungary, Bulgaria and Romania) for which the monetary factor has assumed an ever more important role in underpinning manufacturing competitiveness. The picture that emerges from the analysis of social dumping is very different. The increasing role of social dumping represents the principal factor of manufacturing competitive advantage for the first group, while for the second group the importance of social dumping is declining or even disappearing, as is the case of Bulgaria.

The different competitive strategies adopted by the CEE-5 are clearly highlighted in Table (6). This shows the Spearman rank correlation coefficients between time and the CEE- 5 cost advantage and various form of dumping, as defined above, to detect the temporal trend of the variables. In contrast to other parametric technique, like the more usual Pearson's product-moment correlation, Spearman's non parametric correlation test does not require normal distribution of the data and a large sample size (Gauthier, 2001; Bishara \& Hitter, 2012), and therefore it is more suitable for our analysis. A negative sign of coefficients indicates an increasing CEE-5 cost advantage and dumping during the period, while a positive sign a decrease in them. Although it is impossible for some variables to reject the null hypothesis of no temporal trend, the results are still a meaningful source of information for a descriptive analysis. 


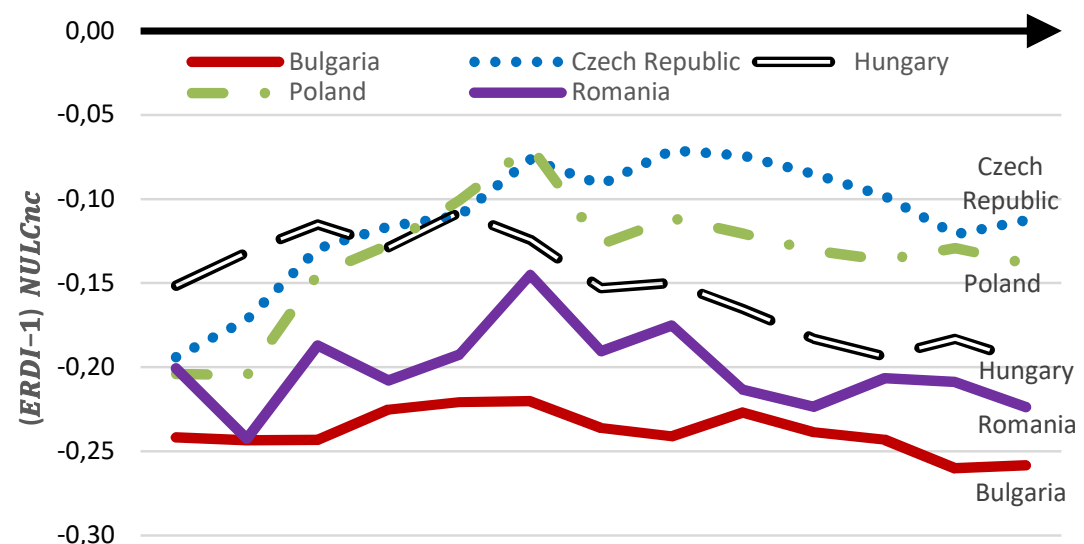

2004200520062007200820092010201120122013201420152016

Figure 2. Monetary dumping in the EU manufacturing industry, 2004-2016 Source: own elaboration based on Eurostat Database.

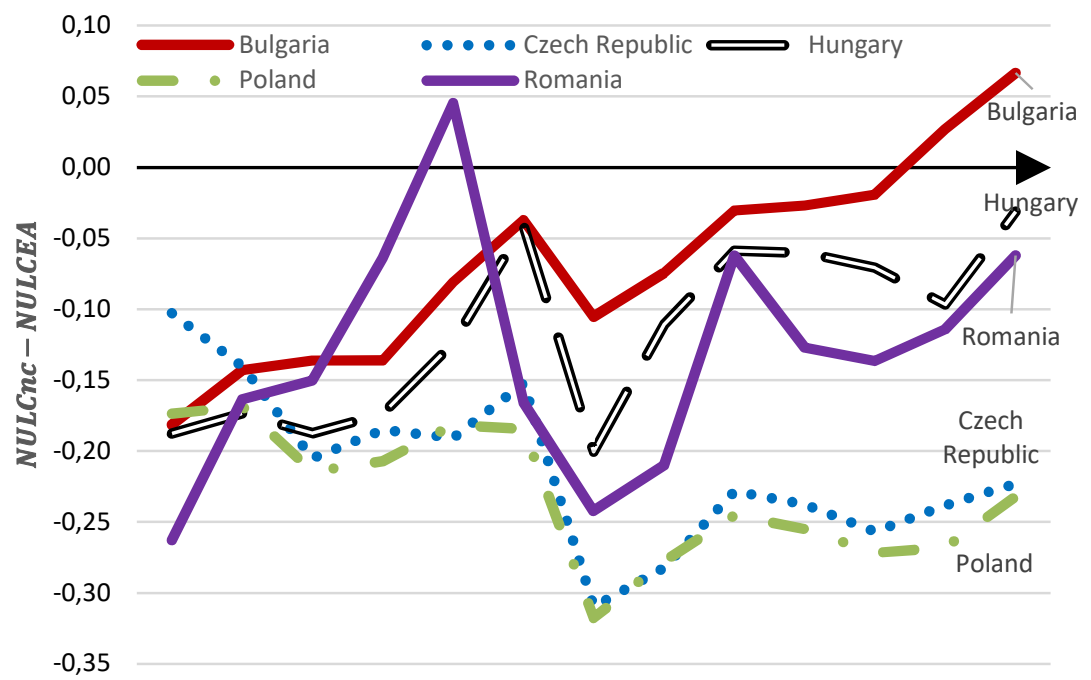

2004200520062007200820092010201120122013201420152016

Figure 3. Social dumping in the EU manufacturing industry, 2004-2016

Source: own elaboration based on Eurostat Database and the European Commission.

The competitive temporal dynamic of the two groups is exactly the opposite during the period. The Czech Republic and Poland gain manufacturing cost-competitiveness by a process of real currency appreciation and a widening wage gap, in all its three dimensions, with respect to the EA. On the contrary, Bulgaria, Hungary and Romania lose manufacturing cost-competitiveness because their real currency depreciation is unable to compensate for the narrowing gross wage gap with respect to the EA. 


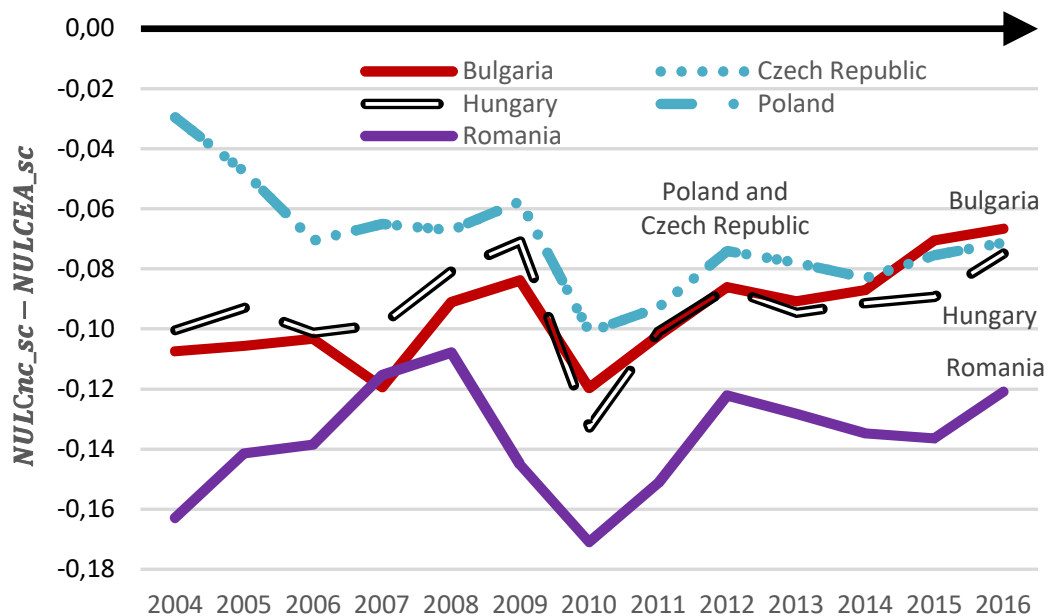

Figure 4. Welfare dumping in the EU manufacturing industry, 2004-2016

Source: own elaboration based on Eurostat Database and the European Commission.

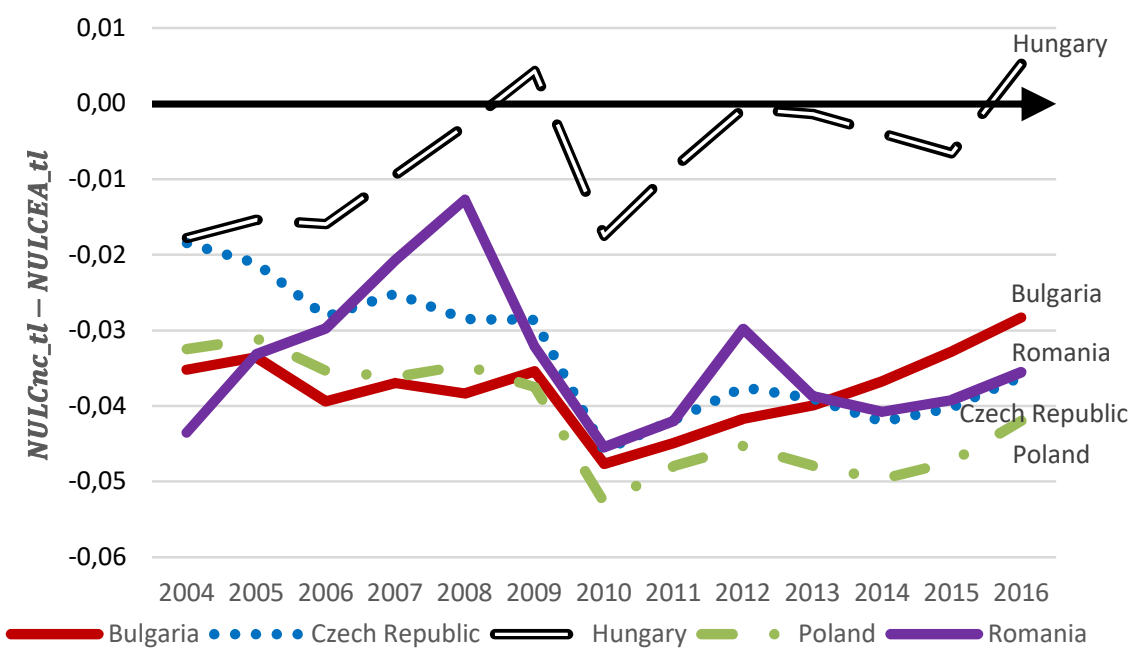

Figure 5. Fiscal dumping in the EU manufacturing industry, 2004-2016

Source: own elaboration based on Eurostat Database and the European Commission.

We can sum up the different competitive strategies adopted by the CEE-5 within the European single market as monetary convergence and wage divergence versus monetary divergence and wage convergence, as shown in Table 7 . The strategy that has proven more effective in improving the manufacturing cost-competitiveness is the first, performed by the Czech Republic and Poland, based on limiting labour costs and a relative strong exchange rate policy.

A similar clustering of countries has been found by Noja (2018), on the basis of the features of structural labour market policies in the CEE economies. Lauzadyte-Tutliene, 


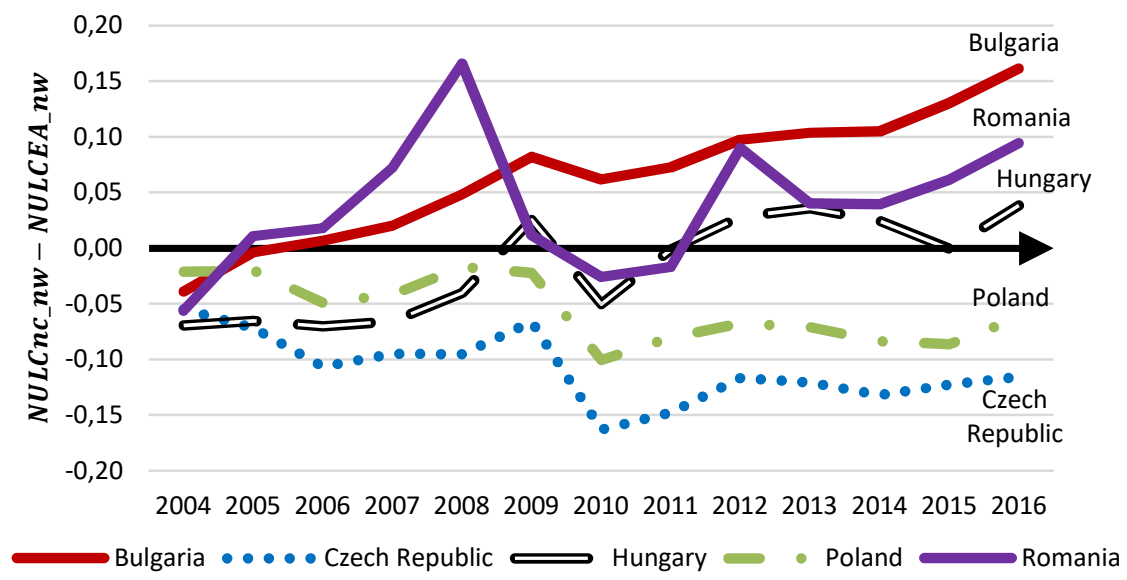

Figure 6. Wage dumping in the EU manufacturing industry, 2004-2016

Source: own elaboration based on Eurostat Database and the European Commission.

Balezentis and Goculenko (2018), instead, categorise Hungary in the first group, alongside the Czech Republic and Poland, by clustering the CEE welfare state models. Regarding wage trends, these results are consistent with Oblath, Palócz, Popper and Valentinyi (2015), showing that in the CEE countries the annual rates of changes in real and nominal labour costs are negatively correlated with their initial levels, lower in the second group of the CEE-5, although the decelerating wage convergence after the crisis of 2008 (Galgóczi, 2017). A possible explanation of the different competitive strategies could refer to the different wage level in the two groups of the CEE-5. As shown by Drahokoupil and Piasna (2018), indeed, Bulgaria, Hungary and Romania have the lowest levels of PPP gross and net wages within the EU, significantly below that of Czech Republic and Poland, notably in manufacturing industry. In these countries, therefore, there would be no room for further wage divergence relative to the EU level.

Table 6. Spearman Rank Temporal Correlation Coefficients of CEE-5 Cost Advantage and Various Form of Dumping

\begin{tabular}{|c|c|c|c|c|c|c|}
\hline Country & $\begin{array}{c}\text { Cost } \\
\text { advantage }\end{array}$ & $\begin{array}{c}\text { Welfare } \\
\text { dumping }\end{array}$ & $\begin{array}{c}\text { Fiscal } \\
\text { dumping }\end{array}$ & $\begin{array}{c}\text { Wage } \\
\text { dumping }\end{array}$ & $\begin{array}{c}\text { Monetary } \\
\text { dumping }\end{array}$ & $\begin{array}{c}\text { Social } \\
\text { dumping }\end{array}$ \\
\hline \multicolumn{6}{|c|}{ Group 1 } & \multicolumn{6}{|c|}{} \\
\hline \multirow{2}{*}{ Czech Republic } & -0.5824 & -0.6813 & -0.7527 & -0.6703 & 0.4780 & -0.6923 \\
& $(0.0436)$ & $(0.0183)$ & $(0.0091)$ & $(0.0202)$ & $(0.0977)$ & $(0.0165)$ \\
\hline \multirow{2}{*}{ Poland } & -0.4010 & -0.5384 & -0.7252 & -0.6923 & 0.2087 & -0.6868 \\
& $(0.1647)$ & $(0.0621)$ & $(0.0120)$ & $(0.0165)$ & $(0.4695)$ & $(0.0174)$ \\
\hline \multicolumn{7}{|c|}{ Group 2 } \\
\multirow{2}{*}{ Bulgaria } & 0.8736 & 0.7417 & 0.0714 & 0.9835 & -0.2692 & 0.9670 \\
& $(0.0025)$ & $(0.0102)$ & $(0.8046)$ & $(0.0007)$ & $(0.3510)$ & $(0.0008)$ \\
\hline \multirow{2}{*}{ Hungary } & 0.5054 & 0.4010 & 0.6593 & 0.8351 & -0.7857 & 0.7032 \\
& $(0.0799)$ & $(0.1647)$ & $(0.0224)$ & $(0.0038)$ & $(0.0065)$ & $(0.0148)$ \\
\hline \multirow{2}{*}{ Romania } & 0.2472 & 0.3076 & -0.2362 & 0.4560 & -0.2857 & 0.4340 \\
& $(0.3917)$ & $(0.2865)$ & $(0.4131)$ & $(0.1142)$ & $(0.3223)$ & $(0.1327)$ \\
\hline
\end{tabular}

In parenthesis the two-tailed p-value of the null hypothesis of no correlation is shown.

Source: own study. 
Table 7. Competitive Strategies of CEE-5 Countries

\begin{tabular}{|c|c|c|}
\hline Competitive strategy & Wage divergence & Monetary divergence \\
\hline Wage convergence & - & Bulgaria, Hungary, Romania \\
\hline Monetary convergence & Poland, Czech Republic & - \\
\hline
\end{tabular}

Source: own study.

\section{CONCLUSIONS}

In recent years, within the EU, the spatial distribution of the manufacturing production has been characterised by a process of relocation from Western countries towards the new CEE member states. This trend has raised much popular and political debate about suspected practices of unfair competition within the European single market, in the form of macroeconomic dumping by the CEE countries. The aim of this article has been to define and estimate the extent of different possible forms of macroeconomic dumping performed by five CEE countries (Bulgaria, Czech Republic, Hungary, Poland and Romania) in the manufacturing industry in the aftermath of the Eastern EU enlargement (2004-2016). In particular, social dumping, deriving from lower welfare benefits, net wages and taxes on labour, and monetary dumping, deriving from real currency undervaluation with respect to EUR, has been analysed. The methodology relied on panel data econometrics and descriptive statistical analysis based on an appropriate decomposition of Nominal Unit Labour Cost expressed in PPP, in order to assess for different forms of dumping. The main limitations concern the small size of data set, reducing the statistical significance of estimation. Further research could extend the period under observations to obtain more consistent estimations, and apply the methodology to another situation within and outside the EU, to compare the relevance of macroeconomic dumping in the current world economy.

The main results can be summarised as follows: a) each of the five CEE countries has a cost competitiveness advantage in the manufacturing industry relative to the $E A ; b)$ during the period considered (2004-2016), the Czech Republic and Poland increased their relative cost competitiveness, while in Hungary, Bulgaria and Romania the cost competitiveness decreased; $c$ ) for each of the CEE countries, the relative cost advantage derives from lower labour costs, so denoting the presence of macroeconomic dumping; d) both forms of dumping, social and monetary, are relevant in explaining CEE-5 production and exports performance in the manufacturing industry; e) social, and particularly monetary dumping are factors hindering progress in CEE-5 labour productivity; e) CEE countries are distinguished by two different competitive strategies since the Czech Republic and Poland manufacturing cost advantage relies essentially on social dumping, while Hungary, Bulgaria and Romania on monetary dumping; e) with regard to forms of social dumping, welfare dumping is present in each of the CEE countries, fiscal dumping plays a very limited role, and wage dumping is present only in the Czech Republic and Poland; f) the competitive strategy based on social dumping has achieved better results, in terms of manufacturing cost-competitiveness, than monetary dumping strategy.

In conclusion, in the early stages of the economic integration of the CEE countries within the institutional framework of the EU, the presence of competitive advantage deriving from lower labour cost, as a consequence of some form of macroeconomic dumping, 
cannot be deemed as a practice of unfair competition incompatible with the common market. Account must be taken of the initial differences in economic development between the transitional CEE economies and the mature market economies of Western member states. This fact, however, should be regarded as a temporary situation required to promote a process of convergence of technological, organisational and structural efficiency in industrial production, as well as of social and labour conditions. If this does not occur, dumping practices represent an obstacle to the development and modernisation of the economies.

\section{REFERENCES}

Adnett, N. (1995). Social dumping and European economic integration. Journal of European Social Policy, 5(1), 1-12. https://doi.org/10.1177/095892879500500101

Alber, J., \& Standing, G. (2000). Social dumping, catch-up, or convergence? Europe in a comparative global context. Journal of European Social Policy, 10(2), 99-119. https://doi.org/10.1177/a012485

Andersen, T.M. (2003). Welfare Policies, Labour Taxation and International Integration. International Tax and Public Finance, 10, 43-62. https://doi.org/10.1023/A:102227691

Artner, A. (2017). Inequalities of Accumulation: The Case of Central and Eastern Europe. In B. SzentIvány (Ed.), Foreign Direct Investment in Central and Eastern Europe (pp. 151-169). London: Palgrave Macmillan. https://doi.org/10.1007/978-3-319-40496-7

Aspinwall, M. (1996). The unholy social trinity: Modelling social dumping under conditions of capital mobility and free trade. West European Politics, 19(1), 125-150. https://doi.org/10.1080/01402389608425124

Athanasenas, A., Chapsa, X., \& Michailidis, A. (2015). Investigating social protection convergence in the EU-15: A panel data analysis. European Research Studies, 18(2), 79-96.

Auboin, M., \& Ruta, M. (2013). The relationship between exchange rates and international trade: a literature review. World Trade Review, 12, 577-605. https://doi.org/10.1017/S1474745613000025

Baiocchi, G., \& Distaso, W. (2003). GRETL: Econometric software for the GNU generation. Journal of Applied Econometrics, 18, 105-10.

Bellak, C., Leibrecht, M., \& Riedl, A. (2008). Labour costs and FDI flows into Central and Eastern European Countries: A survey of the literature and empirical evidence. Structural Change and Economic Dynamics, 19(1), 17-37. https://doi.org/10.1016/j.strueco.2007.03.001

Benkovskis, K., \& Wörz, J. (2012). Non-price competitiveness gains of Central, Eastern and Southeastern European countries in the EU market. Focus on European Economic Integration, 3, 27-47.

Bernaciak, M. (2015). Introduction: social dumping and the EU integration process. In M. Bernaciak (Ed.), Market Expansion and Social Dumping in Europe (pp. 1-23). Abingdon, UK: Routledge. https://doi.org/10.4324/9781315766607

Bierut, B.K., \& Kuziemska-Pawlak, K. (2017). Competitiveness and Export Performance of CEE Countries. Eastern European Economics, 55(6), 522-542. https://doi.org/10.1080/00128775.2017.1382378

Bishara, A.J., \& Hittner, J.B. (2012). Testing the significance of a correlation with non normal data: comparison of Pearson, Spearman, transformation, and resampling approaches. Psychological Methods, 17(3), 399-417. https://doi.org/10.1037/a0028087

Borbély, S., \& Neumann, L. (2015). Similarities and diversity in the development of wages and collective bargaining in Central and Eastern European countries: a comparison of Hungary, Slovakia and the Czech Republic. In G. Van Gyes \& T. Schulten (Eds.), Wage bargaining under the new European Economic Governance (pp. 169-220), Brussels: ETUI. 
Botrić, V., \& Broz, T. (2016). Competitiveness, Trade with the EU and Labour Markets: Challenges for the Western Balkans. South East European Journal of Economics and Business, 11(2), 20-32. https://doi.org/10.1515/jeb-2016-0008

Brander, J., \& Krugman, P. (1983). A 'reciprocal dumping' model of international trade. Journal of International Economics, 15, 313-321. https://doi.org/10.1016/S0022-1996(83)80008-7

Ca' Zorzi, M., \& Schnatz, B. (2007). Explaining and Forecasting Euro Area Exports. Which Competitiveness indicator performs best?. ECB Working Paper n. 833. Frankfurt am Main: European Central Bank.

Caporaso, J.A., \& Tarrow, S. (2009). Polanyi in Brussels: Supranational Institutions and the Transnational Embedding of Markets. International Organization, 63, 593-620. https://doi.org/10.1017/S002081830999009

Cottrell, A., \& Lucchetti, R. (2012). Gretl User Manual. Retrieved on April 29, 2018 from http://ricardo.ecn.wfu.edu/pub/gretl/manual/

Cremers, J. (2016). Economic freedoms and labour standards in the European Union. Transfer, 22(2), 149-162. https://doi.org/10.1177/1024258916635962

Crespy, A., \& Menz, G. (2015). Commission entrepreneurship and the debasing of social Europe before and after the Eurocrisis.JCMS: Journal of Common Market Studies, 53(4), 753-768 https://doi.org/10.1111/jcms.12241

Dautović, E., Orszaghova, L., \& Schudel, W. (2017). Converging in divergent ways: Explaining intraindustry trade between CESEE countries and the EU-15. Economics of Transition, 25(4), 625662. https://doi.org/10.1111/ecot.12132

DiCiccio, C.J., Romano, J.P., \& Wolf, M. (2018). Improving weighted least squares inference. Econometrics and Statistics. [In Press], Available online since 20 June 2018 at https://doi.org/10.1016/j.ecosta.2018.06.005

Drahokoupil, J., \& Myant, M. (2017). Dependent capitalism and employment relations in East Central Europe. In V. Delteil \& V. Kirov (Eds.), Labour and Social Transformation in Central and Eastern Europe (pp. 42-59). Abingdon, UK: Routledge. https://doi.org/10.4324/9781315682112

Drahokoupil, J., \& Piasna, A. (2018). What is behind low wages in central and eastern Europe?. PostCommunist Economies, 30(4), 421-439. https://doi.org/10.1080/14631377.2018.1442037

Erickson, C.L., \& Kuruvilla, S. (1994). Labor costs and the social dumping debate in the European Union. Industrial and Labor Relations Review, 48(1), 28-47. https://doi.org/10.2307/2524624

European Commission. (2009). European Competitiveness Report 2009. SEC (2009)1657 final, Brussels: Enterprise and Industry Directorate-General. https://doi.org/10.2769/21563

Felipe, J., \& Sipin, G.C. (2004). Competitiveness, income distribution, and growth in the Philippines: what does the long-run evidence show?. ERD Working Paper No. 53, Manila, Philippines: Asian Development Bank.

Felipe, J. (2007). A Cautionary Note on the Interpretation of Unit Labor Costs as an Indicator of Competitivenes, with Reference to the Philippines. Philippine Journal of Development, 34(2), 1-23.

Felipe, J., \& Kumar, U. (2011). Unit Labor Costs in the Eurozone: The Competitiveness Debate Again. Working Paper n. 651. New York: Levy Economic Institute Bard College.

Galgóczi, B. (2017). Why central and eastern Europe needs a pay rise. Working Paper 2017.01. Brussels: European Trade Union Institute.

Gautheir, T.D. (2001). Detecting trends using spearman's rank correlation coefficient. Environmental Forensics, 2(4), 359-362. https://doi.org/10.1006/enfo.2001.0061

Gilbert, J., \& Muchová, E. (2018). Export competitiveness of Central and Eastern Europe since the enlargement of the EU. International Review of Economics and Finance, 55, 78-85. https://doi.org/10.1016/j.iref.2018.01.008 
Havlik, P. (2005). Unit labour costs in the new EU member states. Statistika, Czech Statistical Office, No. 4.

He, C., You, R., \& Mo, W. (2009). The Empirical Study on the International Comparison of Labor Cost of Manufacture Sector [J]. Journal of Financial Research, 7, 017.

Hinze, J. (1998). Problems of International Labour Cost Comparisons. Intereconomics, 33(3), 146-152.

Honkapohja, S., \& Korhonen, I. (2013). Restarting growth in Europe after the Great Recession: CEE versus other countries. In E. Nowotny, P. Mooslechner \& D. Ritzberger-Grônwald (Eds.), A new model for balanced growth and convergence: achieving economic sustainability in CESEE countries (pp. 19-35), Cheltenham: Edward Elgar.

Hooper, P., \& Vranlovich, E. (1995). International comparisons of the levels of unit labor costs in manufacturing. International Finance Discussion Papers 527, Board of Governors of the Federal Reserve System (U.S.).

Höpner, M., \& Schäfer, A. (2012). Integration among unequals: How the heterogeneity of European varieties of capitalism shapes the social and democratic potential of the EU. MPIfG Discussion Paper 12/5. Cologne: Max Planck Institute for the Study of Societies. https://doi.org/10.2139/ssrn.2149634

Hyman, R. (2018). What future for industrial relations in Europe?. Employee Relations, 40(4), 56979. https://doi.org/10.1108/ER-02-2018-0056

ILO. (2013). Wages and Equitable Growth. Global Wages Report 2012/13. Geneva, CH: International Labour Office.

International Monetary Fund. (2018). Annual report on exchange arrangements and exchange restrictions. Washington, DC: International Monetary Fund

Jantoń-Drozdowska, E., \& Majewska, M. (2016). Investment Attractiveness of Central and Eastern European Countries in the Light of New Locational Advantages Development. Equilibrium. Quarterly Journal of Economics and Economic Policy, 11(1), 97-119. https://doi.org/10.12775/EQUIL.2016.005

Kaldor, N. (1978). Causes of the slow rate of economic growth in the United Kingdom. In N. Kaldor (Ed.), Further essays on economic theory (pp. 100-138). New York: Holmes \& Meyer.

Kiss, M. (2017). Understanding social dumping in the European Union. European Parliamentary Research Service, PE 599.353. Strasbourg: European Parliament.

Krugman, P. (1995). Increasing Returns, Imperfect Competition and the Positive Theory of International Trade. In G.M. Grossman \& K. Rogoff (Eds.), Handbook of International Economics (pp. 1243-1277, vol. 3). Amsterdam: Elsevier.

Krzywdzinski, M. (2014). Do investors avoid strong trade unions and labour regulation? Social dumping in the European automotive and chemical industries. Work, Employment and Society, 28(6), 926-945. https://doi.org/10.1177/0950017013516692

Kyrkilis, D., Makris, G., \& Hazakis, K. (2016). Economic Crisis and National Economic Competitiveness: Does Labor Cost Link the Two? The Case of the South Eurozone States. In A. Karasavvoglou, D. Kyrkilis, G. Makris, \& P. Polychronidou (Eds.), Economic Crisis, Development and Competitiveness in Southeastern Europe, Theoretical Foundations and Policy Issues) (pp. 23-40). Switzerland: Springer. https://doi.org/10.1007/978-3-319-40322-9_2

Labrianidis, L. (2016). The Moving Frontier: The Changing Geography of Production in Labour-intensive Industries. Oxford, UK: Routledge. https://doi.org/10.1111/j.1944-8287.2009.01049.x

Larsson, A. (1996). Social policy: past, present and future. Transfer: European Review of Labour and Research, 2(4), 724-737. https://doi.org/ 10.1177/102425899600200410

Lauzadyte-Tutliene, A., Balezentis, T., \& Goculenko, E. (2018). Welfare state in Central and Eastern Europe. Economics and Sociology, 11(1), 100-123. https://doi.org/10.14254/2071-789X.2018/11-1/7 
Maslauskaitè, K. (2013). Social competion in the EU: Myths and reality. Studies and Reports, Projects "The single market 20 years on", June. Paris: Jacques Delors Institute.

Meardi, G. (2017). The Fate of the 'Hard'and 'Soft'acquis communautaires in the New Member States. In V. Delteil \& V. Kirov (Eds.), Labour and Social Transformation in Central and Eastern Europe (pp. 137-162). Oxford, UK: Routledge. https://doi.org/10.4324/9781315682112

Meardi, G., Strohmer, S., \& Traxler, F. (2013). Race to the East, race to the bottom? Multi-nationals and industrial relations in two sectors in the Czech Republic. Work, Employment and Society, 27(1), 39-55. https://doi.org/10.1177/0950017012464417

Merlevede, B., Rayp, G., Van Parys, S., \& Verbeke, T. (2011). Do EU15 countries compete over labour taxes? Working Papers of Faculty of Economics and Business Administration, 11/750. Belgium: Ghent University.

Myant, M., \& Drahokoupil, J. (2012). International Integration, Varieties of Capitalism, and Resilience to Crisis in Transition Economies, Europe-Asia Studies, 64(1), 1-33. https://doi.org/10.1080/09668136.2012.635478

Myant, M. (2018). Why are wages still lower in Eastern and Central Europe?. Working Paper 2018.01. Brussels: European Trade Union Institute.

Naz, A., Ahmad, N., \& Naveed, A. (2017). Wage Convergence across European Regions: Do International Borders Matter?. Journal of Economic Integration, 32(1), 35-64. https://doi.org/10.11130/jei.2017.32.1.35

Noja, G.G. (2018). Flexicurity models and productivity interference in C.E.E. countries: a new approach based on cluster and spatial analysis. Economic Research-Ekonomska Istraživanja, 31(1), 1111-1136. https://doi.org/10.1080/1331677X.2018.1456356

Nölke, A., \& Vliegenthart, A. (2009). Enlarging the Varieties of Capitalism: The Emergence of Dependent Market Economies in East Central Europe. World Politics, 61(04), 670-702. https://doi.org/10.1017/S0043887109990098

Oblath, G., Palócz, É., Popper, D., \& Valentinyi, Á. (2015). Economic convergence and structural change in the new member states of the European Union. Discussion Paper 2015/44, Institute for Economics, Hungarian Academy of Sciences.

Oulton, N. (1994). Labour productivity and unit labour costs in manufacturing: the UK and its competitors. National Institute Economic Review, 148(1), 49-60. https://doi.org/10.1177/002795019414800105

Popovici, O.C. (2015). Assessing the impact of the labour market determinants in attracting FDI. Journal of Academic Research in Economics, 7(1).

Ricci, A. (2015). La competitività industriale nell'Unione Europea: un confronto tra I'Italia e i Paesi dell'Europa orientale. Argomenti. Rivista di Economia, Cultura e Ricerca sociale. Terza serie, 1, 91-113. https://doi.org/10.14276/1971-8357.472

Rodrik, D. (2018). Populism and the economics of globalization. Journal of International Business Policy, 1, 12-33. https://doi.org/10.1057/s42214-018-0001-4

Rogoff, K. (1996). The purchasing power parity puzzle. Journal of Economic Literature, 34(2), 647-668.

Romano, J.P., \& Wolf, M. (2017). Resurrecting weighted least squares. Journal of Econometrics, 197(1), 1-19. https://doi.org/10.1016/j.jeconom.2016.10.003

Rozmahel, P., Grochová, L.I., \& Litzman, M. (2016). The Competitiveness of the EU Countries: A Multi-dimensional Cluster Analysis Approach. In P. Huber, D. Nerudova, \& P. Rozmahel (Eds.), Competitiveness, Social Inclusion and Sustainability in a Diverse European Union (pp. 13-36). Cham: Springer. https://doi.org/10.1007/978-3-319-17299-6_2 
Rubery, J. (2011). Reconstruction amid deconstruction: or why we need more of the social in European social models. Work, Employment and Society, 25(4), 658-74. https://doi.org/10.1177/0950017011419718

Scharpf, F.W. (2010). The asymmetry of European integration, or why the EU cannot be a 'social market economy'. Socio-Economic Review, 8, 211-250. https://doi.org/10.1093/ser/mwp031

Siggel, E. (2010). Concepts and measurements of competitiveness: towards an integrated approach. In P. De Grauwe (Ed.), Dimensions of Competitiveness (pp. 95-120). Cambridge, Massachusetts: MIT Press.

Sinn, H. (2008). Social Dumping in the Transformation Process?. In H. Sinn (Ed.), The New Systems Competition (pp. 86-111). Wiley Online Library. https://doi.org/10.1002/9780470774175

Siudek, T., \& Zawojska, A. (2014). Competitiveness in the economic concepts, theories and empirical research. Oeconomia, 13(1), 91-108.

Slavov, S.T. (2017). Exchange Rate Regimes in Central, Eastern and Southeastern Europe: A Euro Bloc and a Dollar Bloc?. IMF Working Paper 17/83. New York: International Monetary Fund.

Sterchi, M., \& Wolf, M. (2017). Weighted Least Squares and Adaptive Least Squares: Further Empirical Evidence. In V. Kreinovich, S. Sriboonchitta, \& V.N. Huynh (Eds.), Robustness in Econometrics (pp. 135-167). Cham: Springer. https://doi.org/10.1007/978-3-319-50742-2

Totev, S., \& Sariiski, G. (2010). Industrial Delocalization in an Integrating Europe. Eastern European Economics, 48(1), 43-63. https://doi.org/10.2753/EEE0012-8775480103

Turner, A.G., \& Golub, S.S. (1997). Towards a system of multilateral Unit Labour Cost-based competitiveness for advanced, developing and transition economies. IMF Working Paper 97/151. New York: International Monetary Fund.

Turner, P., \& Van't Dack, J. (1993). Measuring international price and cost competitiveness. BIS Economic Papers n. 39. Basle, $\mathrm{CH}$ : Bank for International Settlements.

Van Ark, B., \& Monnikhof, E. (2000). Productivity and unit labour cost comparisons: a data base. Geneva: International Labour Organization.

Van Ark, B., Stuivenwold, E., \& Ypma, G. (2005). Unit Labour Costs, Productivity and International Competitiveness. Research Memorandum GD-80. Groningen Growth and Development Centre.

Varian, H.L. (1989). Price discrimination. In R. Schmalensee \& R. Willig (Eds.), Handbook of Industrial Organization (pp. 597-654, vol. 1). Amsterdam: Elsevier.

Vaughan-Whitehead, D. (2003). EU Enlargement versus social Europe? The uncertain future of the European Social Model. Cheltenham: Edward Elgar.

Vaughan-Whitehead, D. (Ed.) (2015). The European social model in crisis: is Europe losing its soul?. Edward Elgar Publishing.

Vecernik, J. (2001). Labour market flexibility and employment security: Czech Republic. Geneva: ILO.

Voicu, A.M., Sen, S., \& Martinez-Zarzoso, I. (2018). Foreign Direct Investment. In A.M. Voicu, S. Sen, \& I. Martinez-Zarzoso (Eds.), Trade, Development and Structural Change: Central and Eastern Europe (pp. 183-294). London: Palgrave Macmillan. https://doi.org/10.1057/978-1-349-59005-6 


\section{Author}

\section{Andrea Ricci}

Assistant Professor of Economics at the University of Urbino (Italy). Phd in Political Economy (Università Politecnica delle Marche) and MA in International Economics (The Graduate Institute, Geneve). His research interests include international economics, political economy and development economics.

Correspondence to: Andrea Ricci, Department of Economics Society and Politics, University of Urbino, via Saffi 42, 61029, Urbino (PU) Italy. E-mail: andrea.ricci@uniurb.it

ORCID (1) http://orcid.org/0000-0002-5392-6785

\section{Acknowledgements and Financial Disclosure}

The author would like to thank the anonymous reviewers for their useful comments and feedback that led to improvement in the value of this article.

\section{Copyright and License}

This article is published under the terms of the Creative Commons

Attribution - NoDerivs (CC BY-ND 4.0) License

http://creativecommons.org/licenses/by-nd/4.0/

Published by the Centre for Strategic and International Entrepreneurship - Krakow, Poland 